\title{
METODOLOGIA HEGELO-MARXIANA E CENTRALIDADE DO TRABALHO
}

\author{
Agemir Bavaresco ${ }^{1}$ \\ Márcio E. Schäfer ${ }^{2}$
}

\begin{abstract}
Resumo
O presente artigo intenta demonstrar a radical indissociabilidade entre método e conteúdo na filosofia social e política de Marx, particularmente em torno da sua apropriação da metodologia hegeliana. Seguindo a interpretação de Flickinger, a primeira parte do artigo visa articular essa apropriação a partir de um conjunto de tópicos nucleares da filosofia de Marx. Já num segundo momento, o artigo foca num conceito absolutamente fundamental tanto em Hegel quanto em Marx, qual seja: o conceito de trabalho. Assim, o presente artigo visa desenvolver a função sistemática deste conceito na elaboração do sistema de Hegel, e as implicações da mesma na filosofia social do Autor. A seguir, fazemos uma reconstituição da crítica de Marx a essa teoria do trabalho e indicam-se alguns rumos que a filosofia social e política de Marx toma face à filosofia hegeliana, particularmente em torno das tensões que emergem numa sociedade em que o trabalho foi erguido ao status de fonte da riqueza ao mesmo tempo em que aqueles que trabalham e a produzem não podem usufruí-la.
\end{abstract}

Palavras-chave: Hegel, Marx, Método, Trabalho.

\begin{abstract}
This paper attempts to demonstrate the radical inseparability between method and content in the social and political philosophy of Marx, particularly around its appropriation of the Hegelian methodology. Following Flickinger's interpretation, the first part of the paper aims to articulate this appropriation from a set of mainly topics of Marx's philosophy. In the second part, the paper focuses in a concept absolutely fundamental in both Hegel and Marx, namely: the concept of labor. Thus, the present paper aims to develop the systematic function of this concept in the working out of Hegel's system, and its implications in the social and political philosophy of the Author. Forthwith, we make a reconstitution of Marx's critique to this theory of labor and we indicate some ways that the social and political philosophy of Marx look like to the Hegelian philosophy, particularly around the tensions that emerge in a society that the work was raised to the status of source of wealth at the same time those who work and produce cannot enjoy it.
\end{abstract}

Keywords: Hegel, Marx, Method, Labor.

\footnotetext{
${ }^{1}$ Professor do Programa de Pós-Graduação em Filosofia da Pontifícia Universidade Católica do Rio Grande do Sul (PUCRS). Doutor em Filosofia pela Universidade de Paris 1. Site: www.abavaresco.com.br. E-mail: abavareco@pucrs.br

${ }^{2}$ Doutorando em Filosofia pela Pontifícia Universidade Católica do Rio Grande do Sul (PUCRS). E-mail: marcio_schafer@hotmail.com
} 


\section{Hegel e Marx: Metodologia, política e historia ${ }^{3}$}

No primeiro capítulo, "o conceito e a realidade social - o envelhecimento de um jovem hegeliano", Flickinger trata da "preocupação de Marx com a filosofia hegeliana, tornando-se a base de seu desenvolvimento da crítica da economia política e provocando, também, correções importantes no seu próprio pensamento social” (MH, p. 21). Marx escreve, de 1839 até 1844, a sua dissertação sobre a Diferença entre as Filosofias da Natureza de Demócrito e Epicuro e os Manuscritos de Paris, conhecidos sob o título de Manuscritos Econômico-Filosóficos. Ele mantém uma aproximação com a força metodológica e sistemática da filosofia hegeliana, embora seja crítico de sua filosofia política, reconhece a sua capacidade construtiva como base irrecusável de seu pensamento no diagnóstico da sociedade moderna. Flickinger apresenta a teoria social marxiana, a qual não é redutível à teoria econômica. Por isso, ele começa com a Dissertação como primeiro passo analítico.

\section{a) Dissertação e o conceito de movimento}

Marx pensa a possibilidade de compreender o mundo a partir do conceito, isto é, a reconstrução da realidade a partir do desdobramento de um princípio: conceber (concipere) a realidade na sua constituição interna. Na sua dissertação, reconstrói uma discussão grega, assim revaloriza a teoria epicurista contra a de Demócrito, com o objetivo de compreender melhor a filosofia sistemática hegeliana. A tese marxiana apoiase na ideia hegeliana de autonomia e de autoconsciência. "A compreensão da realidade decide-se através da capacidade autorreflexiva do princípio teórico pressuposto, que, neste caso, era o conceito do átomo, revelado através da determinação do movimento" (MH, p. 25).

Marx entende que o princípio da autonomia do pensamento explicita-se na teoria epicurista do movimento e da determinação lógica dos átomos: “A teoria do movimento dos átomos, na filosofia epicurista, foi compreendida como paradigma do conhecimento baseado na capacidade autorreflexiva, ou seja, autônoma, do conceito principal, o átomo" (MH, p. 27). O conhecimento objetivo realiza-se por uma teoria conceitual-

\footnotetext{
${ }^{3}$ Num primeiro momento faremos a reconstituição, sobretudo do tópico metodológico do livro de FLICKINGER, Hans-Georg. Marx e Hegel. O porão de uma filosofia social. Porto Alegre: LPM, 1986. Esta obra será citada assim: MH.
}

\begin{tabular}{|l|l|l|l|l|}
\hline Revista Dialectus & Ano 1 & n. 1 & Julho-Dezembro 2012 & p. 156-186 \\
\hline
\end{tabular}




\section{Agemir Bavaresco / Márcio E. Schäfer}

construtiva, superando um pensamento imediato e positivista pela mediação reconstrutiva de conceitos e teorias. Trata-se de encontrar uma teoria adequada para compreender a realidade.

\section{b) Filosofia política hegeliana: contradições da vontade livre}

A recepção da obra hegeliana por Marx dá-se através da Crítica do Direito Hegeliano do Estado, Introdução à Crítica da Filosofia do Direito e Crítica da Dialética e Filosofia Hegeliana em Geral. Marx assume os resultados da crítica ao cristianismo feita por Feuerbach: reconstrução do "mundo invertido" em que uma comunidade busca realizar a sua ideia de liberdade universal fora da realidade concreta, isto é, na religião. Inverter o mundo ideal para o mundo concreto. Depois, ele assume o mundo invertido, descrito na crítica à religião, para analisar a Filosofia do Direito hegeliana como realidade abstrata da ideia de liberdade. Flickinger destaca que Marx valoriza Hegel frente aos "jovens hegelianos" (David Strauss, Bruno Bauer, L. Feurbach e Max Stirner) e opõe-se “à interpretação que denuncia o filósofo como 'idealista', pelo menos no que diz respeito à potência objetiva de sua teoria" (MH, p. 44).

A Filosofia do Direito de Hegel descreve a base ideal proclamada nas revoluções burguesas e a sociedade pós-feudal que enuncia os princípios universais da comunidade: liberdade e igualdade. Esses princípios são constituídos juridicamente, garantindo que a vontade livre, particular e autônoma, institua a propriedade privada. As formas jurídicas asseguram apenas as relações de posse e troca, ou seja, o direito de propriedade. Marx afirma que tais relações pessoais são uma coisificação: "No caso do trabalho assalariado e da mercadoria, a coisificação exige a subordinação das pessoas sob os fins e a racionalidade das coisas mesmas, fato este não limitado, senão possibilitado pelas estruturas jurídicas” (HM, p. 46). No entender de Flickinger, a crítica marxiana dirige-se à fundamentação jurídica do Estado liberal ou do Estado de Direito. A metodologia hegeliana identifica obrigações e direitos: "Nessa identidade da vontade universal e da vontade particular, obrigações e direito, com isso, unem-se em um, e o homem, mediante o ético, tem direitos na medida em que ele tem obrigações e obrigações na medida em que ele tem direitos" (FD, $\S 155)^{4}$. Flickinger entende que esta limitação mútua dos deveres e dos direitos pessoais na sociedade civil e no Estado

\footnotetext{
${ }^{4}$ HEGEL, G. W.F. Linhas Fundamentais da Filosofia do Direito. Trad. Paulo Meneses et al. São Paulo: Loyola, UNISINOS, UNICAP, 2010.
}

\begin{tabular}{|l|l|l|l|l|} 
Revista Dialectus & Ano 1 & n. 1 & Julho-Dezembro 2012 & p. 156-186 \\
\hline
\end{tabular}


“implica a obrigação de realizar a política com os meios e nos limites da razão imanente do direito, limites objetivos do poder político advindos da impossibilidade de subsumir as relações sociais involuntárias, isto é, coisificadas sob as determinações jurídicas” (MH, p. 50). O poder político do Estado é limitado tanto na vida social e econômica da sociedade, como no seu modo de reprodução.

Marx concorda com o diagnóstico hegeliano sobre as contradições do direito e da sociedade civil que regula as relações sociais e garante a privacidade dos interesses particulares. Hegel é consciente da "miséria provocada pelo processo específico da reprodução capitalista". O que intriga Marx é o Estado, de modo que ele critica "a suposta conciliação das contradições pelo poder do Estado de Direito” (MH, p. 52).

\section{c) Fatos econômicos da sociedade capitalista: propriedade e trabalho}

Marx está convencido de que a dialética hegeliana compreendida como autorreflexão pode dar-lhe um instrumento metodológico de crítica da base sociomaterial do capitalismo. A metodologia da Fenomenologia do Espírito descreve a experiência da consciência ingênua, visando à reflexividade constitutiva do saber em autoconsciência, tematizada na figura do "senhor e escravo", que pode ser lida como "a socialização material da consciência autorreflexiva entre duas pessoas agentes" (MH, p. 61), através de uma luta por reconhecimento assimétrico: “O próprio escravo não pode transmitir sua autonomia ao senhor, nem mesmo voluntariamente, já que não é, por definição, senhor de si mesmo. Reconhecimento fraquíssimo que se deve à repressão permanente de um ser em si mesmo dependente" (MH, p. 62). É este modelo autorreflexivo da autoconsciência que Marx usa para analisar o trabalho alienado e os fatos econômicos da sociedade capitalista: propriedade privada e trabalho produtivo.

O método dialético hegeliano implica uma dupla negação: "negação da negação" que é o movimento negador em dois momentos, a consciência relaciona-se com o mundo objetivo ( $1^{\circ}$ passo da negação: consciência imediata ingênua) e, depois, a consciência reconhece a oposição entre sujeito e objeto, dando-se conta deste primeiro passo, constituindo o pensamento e o objeto como conhecimento objetivo $\left(2^{\circ}\right.$ passo da negação: consciência mediatizada reflexionante). Marx encontra nisso uma estrutura reflexiva e contraditória aplicando esta "autogeração fenomenológica da consciência à autogeração concreta no trabalho como processo autorreflexivo da realização da essência humana" (MH, p. 67). O modelo da estrutura da autoconsciência permite 
compreender as contradições do trabalho que impedem o ser humano de reconhecer-se nos produtos de seu próprio trabalho, gerando o fenômeno da alienação. Em Hegel, a consciência exterioriza-se e retorna em si. Quando este processo não se realiza, ocorre a alienação, ou seja, a perda da determinação reflexiva. Marx aplica este modelo para interpretar os fatos econômicos: trabalho alienado e propriedade privada (Manuscritos, 1844). Há uma coisificação das relações sociais, ou seja, o processo de objetivação do produto do trabalho (o objeto produzido) não é mais reconhecido como produto de seu trabalho.

Os economistas clássicos ingleses de sua época descrevem a propriedade privada como um "fato bruto", por seu turno, Marx mostra que "não é a propriedade privada que fundamenta o trabalho alienado, senão que o trabalho alienado é a origem da propriedade privada - e, em última instância, do capital como riqueza acumulada” $(\mathrm{MH}$,

p. 76). Expresso de outra forma, as diferentes expressões reflexivas da propriedade privada existem simultaneamente: “(a) enquanto trabalho, (b) enquanto capital, isto é, enquanto forma materializada e dessubjetivizada do trabalho, e (c) enquanto relação entre o trabalho do homem e o capital como acumulação deste trabalho" (MH, p. 77).

\section{d) História e consciência: Reflexividade material da história ${ }^{5}$}

A metamorfose da história mundial é a evolução do modo de produção, da divisão do trabalho e do comércio, que se dá entre as diversas nações. Marx e Engels fazem uma leitura material da história: "Essa metamorfose da história em história mundial não é um simples ato abstrato da 'consciência de si', do 'espírito do mundo' ou de qualquer outro fantasma metafísico, mas um ato puramente material, empiricamente demonstrável, um ato em que qualquer indivíduo que come, bebe e se veste é uma ilustração viva disso" (IA, p. 1069). Marx anota, na margem do seu livro Ideologia Alemã: "Sobre a produção da consciência", afirma "que a libertação de cada indivíduo se realizará na medida em que a história será transformada completamente em história mundial" (IA, p. 1070). Aqui, pode-se entender que a produção da consciência envolve a reflexividade material e internacional. Essa reflexividade compreende as relações

\footnotetext{
${ }^{5}$ MARX, K. e ENGELS, F. Histoire et conscience. In: Idéologie Allemande. Trad. Maximilien Rubel. Paris: Gallimard, 1982, p. 1069-1085. Usaremos a abreviação IA. Em português este texto foi traduzido por Ione de Andrade: A produção da consciência. In: Karl Marx. Sociologia. Org. Octavio Ianni. São Paulo: Ática, 1980, p. $145-158$.
}

\begin{tabular}{|l|l|l|l|l|} 
Revista Dialectus & Ano 1 & n. 1 & Julho-Dezembro 2012 & p. 156-186 \\
\hline
\end{tabular}


reais, libertando-se das "barreiras nacionais e locais, colocando-se em relação prática com a produção (aí compreendido aquela do espírito) do mundo inteiro" (IA, p. 1070).

Marx e Engels opõem à concepção idealista de história baseada em categorias para tipificar os diferentes períodos históricos, a teoria da história como processo real de produção material da vida cotidiana. Porém, eles entendem que há uma reflexividade entre história e consciência: "Esta concepção de história mostra que as circunstâncias fazem os homens tanto quanto os homens fazem as circunstâncias" (IA, p. 1072).

Eles, ademais, compreendem que as circunstâncias em que uma classe dominante é hegemônica, ela refletirá suas ideias dominantes, ou seja, ela determinará as circunstâncias. "Os pensamentos dominantes são a expressão em ideias das condições materiais dominantes, essas são condições concebidas como ideias, portanto a expressão das relações sociais que fazem justamente de uma única classe, a classe dominante, portanto as ideias de sua supremacia” (IA, p. 1081). Há uma reflexividade das condições sociais de um modo de produção dado, por isso, não se trata de escrever a história apenas como progressão do conceito, mas apresentar a reflexividade destes processos imbricados em suas circunstâncias reais.

A preocupação dos autores é mostrar que a consciência histórica está vinculada à sua materialidade. Há níveis de consciência que refletem as esferas da evolução histórica. Assim sendo, a metodologia da autoconsciência reflexiva é mantida para compreender a história como reflexão do movimento econômico e, ao mesmo tempo, como reflexão dos pensamentos dos atores coletivos.

\section{Lógica hegeliana, Grundrisse e Capital marxiano}

Marx quer encontrar um procedimento analítico para analisar a economia, especificamente, o movimento do capital. Nesse caso, a estrutura autorreflexiva da consciência autônoma hegeliana pode ser usada para compreender a estrutura do capital? A hipótese de Marx é a seguinte: partir da racionalidade do capital como um todo, isto é, o processo inteiro da reprodução material para compreender os condicionamentos sofridos pela sociedade burguesa na medida em que ela sujeita-se ao poder do capital. Ele precisa tematizar a autonomia e a liberdade humana deformadas a partir da constituição material do poder do capital, fato que não permitia mais o uso afirmativo do modelo da autorreflexividade da consciência. Aqui, reside o problema da 
discussão com os socialistas utópicos representados, sobretudo, em Pierre-Josef Proudhon e seu livro A Filosofia da Miséria.

\section{a) Filosofia da Miséria X Miséria da Filosofia}

Marx critica Proudhon pela sua fraca consciência metodológica, pois tomava, em seu livro Filosofia da Miséria, os fatos econômicos apenas como exemplos de suas análises. Marx, pois, escreve a Miséria da Filosofia (1847) como uma obra de combate político em relação aos socialistas utópicos, os quais queriam propor uma nova sociedade sem analisar o tema do trabalho alienado. Neste sentido, Marx começa a analisar o capital com uma nova variante metodológica e entende que o capital é autoconstitutivo, ou seja, ele tem autonomia. Há como uma espécie de internalização das estruturas autorreflexivas no processo de constituição do capital. Trata-se, dessa forma, de analisar os vários fatos econômicos numa interdependência mútua e com um método específico. Marx critica a má metafísica de Proudhon, demonstrando que ele acreditava no "uso produtivo da forma metafísica da reconstrução da economia política" (MH, p. 94). Tal constatação pode ser verificada no título do segundo capítulo da Miséria da Filosofia: "A metafísica da economia política”. É isso que ele faz: Falar, ao mesmo tempo, a linguagem metafísica e aquela da economia política.

\section{b) Capital e metafísica: Rede complexa de movimentos reflexionantes}

Marx articula a relação entre aparecer econômico e determinações lógicas reflexivas a partir do modelo lógico hegeliano, usando o modelo das determinações reflexionantes da Ciência da Lógica para entender a totalidade do processo de reprodução material da sociedade capitalista. A estratégia da Lógica hegeliana é apresentar o pensamento de modo imanente, fundamentando-se numa circularidade reflexiva. Para isso, Hegel começa na Lógica do Ser com o pensamento autofundamentando-se. Ele tematiza o conteúdo de forma negativa: imediato e indeterminado, ou seja, sem determinação e sem reflexão. Depois, na Lógica da Essência, aparecem as estruturas internas do Ser como autorreflexivas: Identidade, Diferença (Oposição) e Contradição. Marx interessa-se pela "função metodológica da categoria do aparecer [...] como centro lógico na análise do capital” ( $\mathrm{MH}$, p. 102). A Essência é o próprio Ser suprassumido aparecendo em si e para si como autorreflexivo.

\begin{tabular}{|l|l|l|l|l|} 
Revista Dialectus & Ano 1 & n. 1 & Julho-Dezembro 2012 & p. 156-186 \\
\hline
\end{tabular}


Marx identifica o Ser imediato na mercadoria que aparece como Essência na análise do capital. Porém, o conceito decisivo na recepção da Ciência da Lógica por Marx é a contradição: centro da tensão reflexionante, para a "reconstrução marxiana do capital enquanto constituído pela sua relação interna autocontraditória” (id. p. 104). A contradição é formada pela determinação da diferença compreendida como oposição. Os polos de uma oposição tornam-se determinações reflexionantes autônomas. A autonomia do pensamento, como totalidade, tem uma estrutura dupla, isto é, cada lado dos polos está em relação consigo mesmo e com o outro e o contém. Trata-se de uma unidade de reflexão que inclui e exclui os seus momentos opostos, daí ser chamado de "contraposição contraditória". "Tal determinação atrairia Marx, que faria dela a relação reflexionante dentro da constituição do capital, deixando de lado aquela que, em Hegel, aparece sob a denominação já meio conciliadora da "contradição"” (id. p. 105), ou seja, para Marx a relação entre capital e trabalho está numa contraposição antagônica inconciliável. A rede categorial, na dialética marxiana, organiza os fatos econômicos segundo uma lógica interna reflexionante, que será aplicada nos Grundrisse e no Capital.

\section{1 - Os Grundrisse. Esboços da crítica da economia política}

A finalidade dos Grundrisse (1857-1858) é analisar criticamente as categorias da economia burguesa usadas pelos economistas de seu tempo, ou seja, fazer uma reconstrução crítica da totalidade do capital como movimento material em categorias reflexionantes abstratas. Para isso, Marx reorganiza as determinações abstratas da economia tradicional e elabora a categoria de "concreto" entendido como uma estrutura diferenciada da sociedade a partir de uma rede categorial. Concreto é a síntese de muitas determinações, isto é, uma unidade do múltiplo. O concreto aparece no pensamento como o processo de síntese, como resultado mediatizado e não como ponto de partida, embora seja o ponto de partida para a percepção e a representação imediatas. "O método de ascender do abstrato ao concreto só é a maneira de procedimento do pensamento para se apropriar do concreto, para reproduzi-lo como algo concreto pensado" (id. p. 116), afirma Marx, fazendo referência a Ciência da Lógica. O capital será o princípio de síntese e mediação da sociedade: a totalidade será reproduzida em nível categorial na rede reflexionante autônoma do pensamento. "O capital é o poder econômico 
dominador da sociedade burguesa. Tem que tornar-se o ponto de partida, tal como o ponto final" (id. p. 118).

Os Grundrisse são compostos por dois capítulos: O primeiro trata do "dinheiro" enquanto apresenta o meio mais abstrato e indeterminado no movimento das mercadorias; e o segundo é denominado "capital", ou seja, o dinheiro como capital devido à sua referência à relação lógica entre aparência e essência.

O primeiro capítulo analisa o dinheiro como o Ser do capital, trata-se da determinação das funções do dinheiro dentro do processo da circulação como medida, meio e sujeito. "A mediação de troca das mercadorias é expressa através da função organizadora do dinheiro, manifestando-se na fórmula 'mercadoria-dinheiromercadoria"” (M-D-M), na qual as mercadorias figuram como pressuposto e resultado da relação (id. p. 121). Aqui, o dinheiro é expressão do valor de troca, porém, ele tem uma autonomia e onipresença dominadora, desligando-se das qualidades das mercadorias em sua condição de concreto substrato do valor de troca. A fórmula M-D- M em que o dinheiro é o meio da circulação da mercadoria ainda não descreve o processo capitalista baseado apenas no dinheiro como dinheiro. Aquela fórmula é, pois, substituída pela fórmula dinheiro-mercadoria-dinheiro (D-M-D), visto que o dinheiro torna-se o ponto de partida e o resultado da circulação, ou seja, o dinheiro não é mais meio de troca, mas sujeito de todo processo.

O segundo capítulo trata do dinheiro que aparece como "capital", porém, Marx quer explicar a gênese da circularidade aparente do dinheiro, considerado o "primeiro motor" da reprodução do capital. Não é o dinheiro que reproduz a mercadoria como dinheiro, mas é o trabalho reduzido ao valor de troca. Assim sendo, é o trabalho que constitui o valor de troca a partir da produção material da mercadoria e a sua transformação em dinheiro. Para isso, Marx descreve a "formação do conceito de capital": (1) a forma do Ser imediato do capital como dinheiro: o conceito simples de capital como valor surgindo da circulação; (2) a gênese material da mercadoria como produção material: o capital como pressuposição e resultado da produção; (3) e o valor de troca como capital mostra a identidade contraditória entre circulação e produção. No entender de Flickinger, nos Grundrisse, Marx subordina, por demais, o material ao "lógico" da Ciência da Lógica de Hegel. Porém, é no Capital que a substância social da gênese produtiva será descrita na sua dinâmica das relações sociais.

\section{2 - Capital e Trabalho}

\begin{tabular}{|l|l|l|l|l|} 
Revista Dialectus & Ano 1 & n. 1 & Julho-Dezembro 2012 & p. 156-186 \\
\hline
\end{tabular}


Marx inicia o Capital com a análise da mercadoria (cap. 1), depois, o processo de troca (cap. 2) e, finalmente, o dinheiro ou a circulação das mercadorias (cap. 3). "Na passagem da lógica do aparecer essencial àquela do Ser do capital, encobre-se o passo material invertido da mercadoria ao dinheiro, isto é, o passo da materialidade imediata do capital (= mercadoria) à materialidade mediatizada (= dinheiro)" (id. p. 135). A função sintética do dinheiro é apresentada a partir da gênese da constituição da mercadoria, a qual se reproduz, esquecendo de seus momentos substanciais, restando apenas o seu aparecer imediato lógico no dinheiro. "Marx começa com a determinação materialmente complicada e logicamente abstrata (a mercadoria) para chegar ao dinheiro enquanto expressão materialmente abstrata e logicamente complexa” (id. p. 144). Há uma lógica que segue o caminho da transformação material do produto- mercadoria em dinheiro, que é a lógica do capital que se esquece dos momentos materialmente substanciais da mercadoria que são as condições de sua gênese concreta como produto do trabalho humano. "Em outras palavras, o início e o resultado da transformação da mercadoria são idênticos sob o aspecto de seu alcance objetivo- material, mas diferenciados no que diz respeito à sua estruturação reflexiva, ou seja, com respeito a suas formas logicamente recompostas" (id. p. 144).

\section{a) Duplo valor do trabalho incorporado na mercadoria}

A teoria nuclear de Marx é o "duplo caráter do trabalho representado nas mercadorias", isto é, como valor de uso e de troca. A função mais simples do trabalho é a formação do objeto material como um produto de uso, ou seja, o trabalho está ligado à determinação do valor de uso. Neste processo, ocorre a substituição do "trabalho" por "força de trabalho"; há a quantificação de um quantum de trabalho empregado na fabricação da mercadoria. Aqui, há a perda do aspecto qualitativo da mercadoria que o trabalhador emprega além do quantitativo. Flickinger apresenta três conceitos que se relacionam com este duplo valor do trabalho posto na mercadoria: a produção, a racionalidade e a transformação do trabalho em mercadoria: o processo de coisificação.

(i) Trabalho e Produção: A quantificação do trabalho elimina ou abstrai todos os momentos qualitativos da pessoa ou do sujeito produtor na produção da mercadoria. Trata-se da substituição do trabalhador-sujeito pela medição ou quantificação objetiva da produção, que é chamada "fetichização" da força produtiva. O fetichismo da força

\begin{tabular}{|l|l|l|l|l|} 
Revista Dialectus & Ano 1 & n. 1 & Julho-Dezembro 2012 & p. 156-186 \\
\hline
\end{tabular}


produtiva é a transformação da qualidade em quantidade e a exclusão da práxis como categoria social marxiana em sua condição de prática social-emancipatória.

(ii) Trabalho e Racionalidade: A nova racionalidade é a quantificação da força de trabalho, em que ocorre a redução do trabalho em algo invisível pela eficiência da produção. Em síntese, essa racionalidade dá-se pelo trabalho fisiológico quantificado e pelo trabalho que se torna uma mercadoria, um produto, uma coisa. Com isso, chega-se ao momento da descrição da transformação do trabalho como valor de uso em valor de troca através da mercadoria.

(iii) Trabalho e Mercadoria: A relação de troca de mercadorias descreve a expressão do valor contido nas mercadorias através do dinheiro. Trata-se de mostrar a função constitutiva do trabalho e a sua integração na rede reflexionante do valor de troca. Para isso, Marx diferencia entre a forma relativa de valor e a forma equivalente. Ele compara duas mercadorias diferentes, A e B, por exemplo, o linho (forma relativa de valor) e o casaco (forma equivalente de valor). O linho expressa o seu valor no casaco, de tal forma que a mercadoria linho tem um papel ativo, enquanto a mercadoria casaco é passiva. A primeira tem um valor relativo, autônomo, ativo e dominante; e a segunda tem um valor equivalente servil, passivo e dependente. Marx aplica, aqui, a relação reflexionante hegeliana da oposição contraditória para interpretar a gênese do capital (cf. p. 154). O valor em forma relativa e equivalente, neste exemplo, mostra a oposição contraditória que ao mesmo tempo está em relação e exclui-se na estrutura do valor de troca de uma mercadoria. Isto será aplicado à deformação do trabalho humano que se torna idêntico à mercadoria, isto é, servil, subordinado à constituição do dinheiro-capital como sua forma específica: forma equivalente de valor. Segundo Flickinger, no momento em que a mercadoria B é integrada na relação de valor, funcionando como forma equivalente, isto é, passiva e servil, ela sofre duas mudanças:

(a) o seu ser produto útil torna-se simples meio, desnaturando-se na forma de aparente valor em função alheia; (b) reduz a sua materialidade concreta em uma expressão quantitativa, reprimindo as suas qualidades. Em conclusão, a autodeterminação do valor de uma mercadoria constitui-se à custa de outra, esquecendo toda a gênese social, reduzindo-se à sua forma equivalente de valor quantitativo. "Neste tipo de relação reflexionante entre as duas mercadorias em jogo, a própria gênese da mercadoria como produto concreto do trabalho do homem acaba necessariamente por desaparecer" (id. p. 157), ou seja, o trabalho concreto converte-se no seu oposto, o trabalho humano abstrato. Há uma oposição interna na mercadoria que se camufla em outra externa no

\begin{tabular}{|l|l|l|l|l|} 
Revista Dialectus & Ano 1 & n. 1 & Julho-Dezembro 2012 & p. 156-186 \\
\hline
\end{tabular}


fenômeno que envolve duas mercadorias: A antítese interna dá-se entre o valor de uso e valor contido nela; a oposição externa dá-se entre duas mercadorias, em que uma expressa o valor de uso e a outra, o valor de troca, "como dinheiro-capital, enquanto autodisjunção reflexiva entre sua forma aparente e sua substância” (id. p. 158).

\section{b) Dinheiro, forma equivalente e fetichismo da mercadoria}

O cidadão negocia com o "dinheiro" que é, nesta condição, a forma equivalente da mercadoria. Porém, o que ocorre nesse "passo material encoberto no caminho da 'essência à aparência', ou da mercadoria até o dinheiro, o homem-sujeito cai no esquecimento" (id. p. 158). Marx expõe a constituição da mercadoria antes de tematizar o dinheiro-capital para mostrar o encobrimento do trabalhador-sujeito pela mercadoria, fenômeno denominado "fetichismo da mercadoria".

O fetichismo da mercadoria esconde e inverte os momentos de sua formação, em que ocorre a "subjetivação dos produtos-mercadoria" e a "objetivação dos sujeitostrabalhadores". Desse modo, as mercadorias tornam-se autônomas e constituem a sociedade, pois "a mercadoria, manifesta-se como forma-sujeito da síntese social da sociedade e os sujeitos da produção tornam-se, ao nível da troca, objetos, e os objetos da produção fazem-se os sujeitos da troca” (id. p. 160). Este é o fetiche da mercadoria que reflete a relação social dos trabalhadores com o trabalho total como uma relação social que lhe escapa do domínio, visto que se torna um movimento autônomo das mercadorias em forma de dinheiro-capital.

\section{A centralidade do trabalho}

As considerações precedentes, sob diversos aspectos, demonstram que um conceito assume uma posição no arcabouço teórico-conceitual de teoria hegeliano- marxiana, a saber, o conceito de trabalho. No que se segue, interessa, sobretudo, desenvolver brevemente a função lógico-sistemática do referido conceito em Hegel e Marx de forma não exaustiva e o seu desdobramento no desenvolvimento das teorias da sociedade moderna de ambos os autores e as conclusões mais significativas acerca da sociedade moderna. 


\subsection{A Forma Lógica do Trabalho}

Uma primeira consideração importante diz respeito à utilização do conceito de trabalho na Logica hegeliana. Para compreender esse ponto, é útil remeter ao $§ 161$ da Enzyklopädie, em que Hegel define a Ideia nestes termos: "a Ideia é o verdadeiro em e para si (an und für sich), a unidade absoluta do Conceito e da objetividade”. Sem volteios, Hegel define a Ideia a partir de dois conceitos que foram desenvolvidos nas duas primeiras partes da lógica do conceito: a subjetividade (Subjektivität) e a objetividade (Objektivität). Naquela, o Conceito tem a si mesmo por conteúdo; nesta, o conteúdo está pressuposto na objetividade, como um independente. A questão inextricável da qual Hegel não pode descurar é: como é possível a passagem da subjetividade, na qual o Conceito tem a si mesmo por conteúdo, para a esfera da objetividade, em que o conteúdo é pressuposto, isto é, um mundo cuja existência não é derivada do próprio Conceito? A categoria de mediação (Vermittlung) exerce, na Ciência da Lógica, a função de solucionador desse impasse.

A categoria de atividade (Tätigkeit) que, aqui, é aproximada a de trabalho $^{6}$ - na medida em que corrobora a realização do Conceito na objetividade -, aparece em sua forma especulativa na Ciência da Lógica. A esse propósito, é salutar fazer uma observação preliminar: o termo Arbeit não é usado por Hegel, na Ciência da Lógica, na acepção que é relevante para a presente pesquisa. Aparece somente uma única vez no fim do breve texto que prefacia o tomo II da referida obra. E Hegel trata de trabalho no sentido de pedir desculpas àqueles a quem a obra destina-se, por não ter dispensado ao seu "Arbeit" o cuidado e o tempo que ele teria exigido. Expresso de outra forma, o termo Arbeit aparece, aqui, num sentido completamente lateral ${ }^{7}$. O quadro não é o mesmo na Lógica da Enzyklopädie, § 162, no qual Hegel usa o termo Arbeit como sendo "um trabalho, o qual é o trabalho da Razão".

No que interessa aqui, a questão do trabalho aparece especificamente na segunda seção da Doutrina do Conceito, no terceiro capítulo que trata da teleologia (Teleologie). O produto da atividade teleológica constitui-se no conjunto de determinações que a subjetividade, o fim subjetivo, inscreveu na objetividade. Dele, resulta que já não mais subsiste uma causalidade do mundo exterior independente da subjetividade - ao menos

\footnotetext{
${ }^{6}$ Evidentemente o trabalho é uma atividade, mas uma atividade específica. É uma atividade de um sujeito que coloca um fim x, concebido na sua subjetividade, na objetividade. Para essa discussão, ver Schmidt am Busch, (2002, cap. 3).

${ }^{7}$ Cf. também Jarczyk (1984, p. 124).
}

\begin{tabular}{|l|l|l|l|l|} 
Revista Dialectus & Ano 1 & n. 1 & Julho-Dezembro 2012 & p. 156-186 \\
\hline
\end{tabular}


no que tange à Ideia absoluta, no que diz respeito ao conhecer e agir humanos. Pelo imiscuir-se do fim subjetivo na objetividade, erige-se a ponte entre a necessidade da objetividade imediata e a liberdade do Conceito. Tem-se, agora, uma unidade fundamental entre ambos, pois as determinações da objetividade adéquam-se às determinações da subjetividade, de modo que o fim subjetivo pode reconhecer-se a si mesmo como uma força que ativamente alterou a objetividade, sendo possível, por intermédio de um perfazer reflexivo dessa, encontrar nela nada mais do que as suas próprias determinações, que foram inculcadas na objetividade com a utilização da potência do meio, da ferramenta. É exatamente em torno do conceito de ferramenta que se situa um ponto de acesso ao conceito de trabalho na Ciência da Lógica.

\subsection{A Dimensão Formadora do Trabalho no Espírito Subjetivo}

Adolfo Sánchez Vázquez, em seu conhecido livro Filosofia da Práxis, indica ao menos três momentos cruciais da gênese e do desenvolvimento do conceito de trabalho na obra hegeliana precedente à Fenomenologia do Espírito. O filósofo afirma: "já encontramos o tema da prática, e concretamente do trabalho, em escritos anteriores à Fenomenologia do Espírito, obra que data de 1807; esses escritos são o Fragmento de sistema (1800), o Sistema de Eticidade (1802) e os cursos da Realphilosophie (1803- 1804 e 1805-1806)" (SÁNCHEZ VÁZQUEZ, 1968, p. 64-65).

A investigação hegeliana do trabalho nos textos que compõem a Realphilosophie traz aproximações importantes com o seu respectivo tratamento na Fenomenologia do Espírito, isto é, na definição do trabalho como a forma de mediação da subjetividade e da objetividade com a qual é possível explicar a autogênese do ser humano em geral. Nestes textos, aparece, pela primeira vez, a inserção da ideia de desejo reprimido (gehemmte Begierde), a qual permite explicar como, através do trabalho, o ser humano instaura as condições para chegar à intuição de si, tendo em vista que diferentemente do puro desejo (Begierde), que literalmente devora o seu objeto, sem deixar vestígios, sendo, portanto, um desejo circunscrito à animalidade, ao agora da naturalidade imediata, que evanesce assim que é satisfeito, o desejo reprimido, ao não devorar o objeto, mas ao transformá-lo, dando-lhe um feitio humano, inscreve-o na temporalidade histórica.

A explicitação da dimensão formadora do trabalho, estruturada a partir da forma lógica do trabalho, tal como ela pode ser exposta a partir da Ciência da Lógica, requer 
que se explicite a mediação entre sujeito e objeto não mais no âmbito do devir do Conceito, mas no percurso da consciência natural, inculta, ao saber absoluto. A consciência, para elevar-se ao saber absoluto, defronta-se com uma objetividade a ser elaborada. Tal elaboração é uma condição imprescindível para que a consciência tornese uma consciência científica.

Precisamente por isso, a doutrina hegeliana de trabalho, não mais como o trabalho do Conceito da Lógica, mas como trabalho propriamente dito, aparece no contexto dos escritos sistemáticos na Fenomenologia do Espírito, numa passagem conhecida como a dialética do senhor e do escravo. Nesta ótica, pressuposto que a realização da verdade da consciência depende de sua relação com um objeto genuíno, há que se investigar como essa relação efetiva-se. No momento da razão observadora, antes de chegar à razão ativa, assevera Hegel,

\begin{abstract}
Em primeiro lugar, esse exterior só torna o interior visível como órgão ou - em geral - faz do interior um ser para um outro, uma vez que o interior, enquanto está no órgão, é atividade mesma. A boca que fala, a mão que trabalha - e também as pernas, se quiserem - são os órgãos que efetivam e implementam, que tem neles o agir como o agir ou o interior como tal. Todavia, a exterioridade que o exterior ganha mediante os órgãos é o ato, como uma efetividade separada do indivíduo. Linguagem e trabalho [grifo dos autores] são exteriorizações nas quais o indivíduo não se conserva nem se possui mais em si mesmo; senão que nessas exteriorizações faz o interior sair totalmente de si, e o abandona a Outro (HEGEL, 1992, p. 198).
\end{abstract}

No desenvolvimento da dimensão formadora do trabalho, três conceitos são absolutamente centrais, quais sejam: Äusserung, Entäusserung e Entfremdung, cuja tradução corrente adotada na literatura filosófica hegeliana brasileira é externação, exteriorização e alienação, respectivamente ${ }^{8}$. A menção ao esquema conceitual é importante, porque permite aprofundar os alcances teóricos ínsitos ao problema do trabalho. Pois embora se esteja, num primeiro momento, realçando a dimensão formadora do trabalho, absolutamente central no percurso de exposição do saber absoluto, esta constitui somente uma das possibilidades intrínsecas ao trabalho, caracterizada pela Entäusserung (exteriorização), que constitui a exteriorização da subjetividade na objetividade, em que ao fim do movimento aquilo que foi exteriorizado retorna à consciência, podendo ela ver-se a si mesma neste seu ser outro gerado na esfera da objetividade - o que contrasta com a mera externação, que é um simples sair

\footnotetext{
${ }^{8}$ Cabe não ignorar que tal opção da terminológica da literatura filosófica sobre Hegel no Brasil se deve muito à tradição francesa. O uso desta terminologia torna-se também por essa razão difundida por pesquisadores brasileiros formados na escola francesa como é caso, por exemplo, de Denis Rosenfield, que em sua obra Política e Liberdade em Hegel usa a tradução aqui utilizada para os referido termos. Quanto a isso, ver também Jarczyk (1984, p. 118).
}

\begin{tabular}{|l|l|l|l|l|}
\hline Revista Dialectus & Ano 1 & n. 1 & Julho-Dezembro 2012 & p. 156-186 \\
\hline
\end{tabular}


de si, sem nenhum compromisso em retornar a si, na qual o externado esvai-se na exterioridade. Neste sentido, o trabalho é tomado numa acepção positiva, pois é a exteriorização, o tornar-se coisa da subjetividade, das potencialidades humanas, que serve de base para que o sujeito possa chegar à sua verdade, ao conhecimento de si.

Precisamente este aspecto expressa a dimensão formadora do trabalho tal como é formulada por Hegel na dialética do senhor e do escravo, em que a consciência escrava conquista a sua verdade pelo refreamento do desejo que, derrotando a imediatidade do desejo desenfreado, inscreve, pela ação mediadora do trabalho, os vestígios de sua subjetividade na exterioridade, podendo, destarte, o escravo reconhecer-se a si mesmo na exterioridade do ser-outro. Assim, é pelo elemento da permanência, pela inscrição da subjetividade na objetividade não destruída, mas elaborada, que a consciência de si escrava chega à sua verdade. Cabe, aqui, destacar, uma vez mais, a profunda agudeza com que Hegel resolve a questão do trabalho em sua filosofia, pois, diferentemente de Aristóteles, para o qual a negação da verdade do escravo, o seu rebaixamento à categoria de instrumento dava-se pela sua vinculação ao trabalho, uma vez que, pelo trabalho, se negava a realização daqueles atributos indispensáveis à realização do ser humano livre, o escravo chega à sua verdade exatamente pelo trabalho.

Pelo trabalho, o escravo chega à verdade de si, liberta-se de toda imediatez, inibindo seu desejo, não estando dominado pela pura naturalidade da vida ou, se assim se quiser, não mais determinado tão-somente pelos impulsos naturais. O escravo elabora um mundo com uma face peculiar, em que ele pode reconhecer-se como autor, isto é, sai do em-si, abandona-se ao outro, reconhecendo-se a si mesmo neste seu ser para outro, isto é, torna-se um em-si e para-si. E isso pela sua capacidade de agir sobre a objetividade dada, mas não com vistas à satisfação de seus desejos imediatos. Assim, o fruto de sua ação responde não ao desejo imediato, mas ao elemento da permanência, que assegura o reconhecimento do escravo a partir daquele seu ser outro, engendrado na exterioridade. Disso resulta que não persiste mais uma subjetividade abstrata nem uma objetividade pura, mas ambas condicionam-se reciprocamente até chegarem ao ápice no saber absoluto.

Desta feita, a interdição do gozo absoluto, refreando o seu desejo de destruição do objeto, característica da consciência natural, é um pressuposto para que o escravo chegue à sua verdade, conquiste a sua liberdade. Assim, pelo trabalho, "o subjetivo se torna objetivo no produto e, desse modo, cria um mundo próprio. O produto de seu trabalho já não é um em si, mas um para si. É possível reconhecer-se nos produtos que 


\section{Agemir Bavaresco / Márcio E. Schäfer}

criou. Transformado a natureza, o escravo reconhece a sua própria natureza" (SÁNCHEZ VÁZQUEZ, 1968, p. 75). É o trabalho que sanciona a efetivação do movimento do emsi, para-si e do em-si e para-si, pois leva a termo a passagem do subjetivo ao objetivo, instaurando as condições objetivas requeridas para que a consciência de si possa chegar à sua verdade.

Ao conceber a verdade do sujeito e do objeto entrelaçadas, Hegel precisa responder como essas duas esferas podem mediar-se com vistas à realização de sua verdade. O trabalho, tão vilipendiado na tradição greco-romana, assume, pela primeira vez, um papel precipuamente positivo, porque ele é, em última instância, um elemento imprescindível para que o sujeito possa chegar à sua verdade. Esse é um resultado cabal da filosofia de Hegel. Porém, quanto ao item (b), Hegel receberá críticas importantes, especialmente de Marx, que vê a concepção de trabalho de Hegel como sendo, ao fim e ao cabo, uma concepção de trabalho espiritual, do trabalho do espírito. Em outras palavras, o trabalho material-concreto é reduzido, por Hegel, ao trabalho do espírito, por isso, como afirma Bourgeois, sucede-se "o rebaixamento do estatuto do trabalho no desenvolvimento do absoluto, tal como o concebe o sistema constituído por Hegel" (BOURGEOIS, 2004, p. 76). Mas não obstante este conjunto de objeções que se pode erguer contra a doutrina hegeliana do trabalho, é inegável que "Hegel levou mais longe do que ninguém a concepção de práxis material produtiva, do trabalho humano, ao relacioná-la, como assinala Marx nos Manuscritos de 1844, com o processo de formação do homem e de sua libertação" (SÁNCHEZ VÁZQUEZ, 1968, p. 78).

\subsection{A Dimensão Formadora do Trabalho no Espírito Objetivo}

O conceito de trabalho ocupa um papel central na constituição do sujeito humano. Isto se buscou realçar na seção precedente. E quando se toma o ser humano como gênero, o trabalho também exerce semelhante grau de importância? Na argumentação que segue, o foco da análise tenciona lançar luz sobre esta questão, buscando destrinchar como o trabalho preenche uma função seminal para que se possa, inclusive, tratar do gênero humano contraposto a outros gêneros.

Essa história exige um querer próprio da comunidade humana, que luta para tornarse uma comunidade ética, que tem e produz na objetividade o seu querer próprio. E aquele povo que leva a termo o seu querer e molda a exterioridade conforme o seu arbítrio, de modo a ver-se a si mesma nesta exterioridade transformada, reconhecendo-

\begin{tabular}{|l|l|l|l|l|}
\hline Revista Dialectus & Ano 1 & n. 1 & Julho-Dezembro 2012 & p. 156-186 \\
\hline
\end{tabular}


se nela, é o que se inscreve no limiar da história universal. Por isso, a asserção de Hegel segundo a qual a África é a-histórica significa que, na África, os povos ainda não superaram a imediatidade do desejo, a vontade natural, ou seja, o espírito ainda não está no espaço e no tempo e, por conseguinte, não há temporalidade histórica.

Desta feita, "sua consciência ainda não chegou à intuição de alguma objetividade fixa, como, por exemplo, Deus ou a lei, na qual o ser humano estivesse em sua vontade e nela tivesse a intuição de sua essência” (HEGEL, 1949a, p. 137). Por isso, escreve Hegel: "Deixamos com isso a África, para mais tarde não tornar a mencioná-la. Pois não é uma parte do mundo histórico, ela não tem movimento e desenvolvimento para mostrar" (1949a, p. 144). Portanto, para Hegel, "tudo o que permanece na forma indeterminada do em-si e da imediação, no estado de inconsciência, de simples possibilidade abstrata, de envolvimento, tudo isto é colocado à margem do curso da história” (ARANTES, 1981, p. 149).

É nítido como Hegel guarda a estrutura desenvolvida na articulação da dimensão formadora do trabalho no Espírito Subjetivo, quando da formação do sujeito, ao tratar da formação do gênero humano, no Espírito Objetivo, representado, aqui, pela categoria "povo". E cabe sublinhar que "povo", para Hegel, é muito mais que um simples conglomerado de indivíduos. O que configura um povo é exatamente o compartilhamento de um conjunto de usos e costumes (a Sittlichkeit), que foram se moldando na história de um povo, desde as gerações pregressas e que passam por atualizações constantes a partir da vida consciente, racional, sobre o conteúdo que se lhe apresenta. A Sittlichkeit, portanto, responde a uma crosta de determinações que um povo adquiriu ao longo de sua história e que lhe dão a sua identidade.

Arantes, quanto a isso, afirma que "é só, pois, na ruptura com a vida imediata que o objeto da História especulativa começa a desenhar-se. A relação entre um povo e sua História só pode estabelecer-se à luz da clareza e da distinção da consciência" (ARANTES, 1981, p. 149).

De modo sintético, quando um povo supera o nível da imediatidade, do desejo desenfreado, não mais dominado pelo "sabor do instante", ele começa a fazer parte do processo de desenvolvimento do espírito, partícipe da história. Com efeito, somente então é que se lhe abre a perspectiva do universal, ao qual, gradativamente, vai acedendo o espírito do povo. A cada determinação histórica que o povo incorpora, ele galga mais um degrau na superação das determinações naturais para ingressar nas determinações espirituais, no reino da liberdade.

\begin{tabular}{|l|l|l|l|l|} 
Revista Dialectus & Ano 1 & n. 1 & Julho-Dezembro 2012 & p. 156-186 \\
\hline
\end{tabular} 


\section{Agemir Bavaresco / Márcio E. Schäfer}

Hegel destrincha o referido problema na sua obra intitulada Linhas Fundamentais da Filosofia do Direito, em que trata do sistema de carecimentos (System der Bedürfnisse), quando analisa as relações econômicas que se levam a termo na bürgerliche Gesellschaft. É instrutivo observar os termos com os quais Hegel inicia a sua análise. No $\S 190$ da obra, afirma Hegel: "o animal possui um círculo limitado de meios e de modos de satisfação de seus carecimentos igualmente limitados”. Como a economia política, Hegel concebe o trabalho, mais precisamente o trabalho abstrato, como solucionador deste impasse natural. Pelo trabalho abstrato, o ser humano, de forma organizada, medeia o dado empírico de tal modo a elevá-lo à condição de satisfazer os seus carecimentos.

À semelhança da economia política, em especial na lapidar formulação de Smith, segundo a qual a divisão do trabalho responde às inconveniências oriundas dos carecimentos humanos, particularmente no mundo civilizado, Hegel concebe a divisão do trabalho como uma nova forma de sociabilidade que emerge destas novas circunstâncias.

\section{O trabalho como atividade "deformadora" do ser humano}

\subsection{O Que é Trabalho Alienado?}

O locus classicus para a análise do problema da face negativa do trabalho, isto é, o problema da alienação, é a crítica que Marx, em seus Manuscritos econômico-filosóficos de 1844, endereça à filosofia hegeliana em geral, mas, em particular, à doutrina hegeliana do trabalho. Afirma Marx:

\footnotetext{
Hegel coloca-se do ponto de vista dos modernos economistas nacionais. Ele apreende o trabalho como a essência, como a essência verdadeira do homem: ele vê somente o lado positivo do trabalho e não seu lado negativo. $\mathrm{O}$ trabalho é o vir a ser para-si do homem dentro da exteriorização ou enquanto homem exteriorizado. $\mathrm{O}$ trabalho que Hegel conhece e reconhece é o trabalho espiritual (2005, p. 133).
}

A elucidação da temática da alienação demanda uma demarcação mais precisa sobre como é possível articular a concepção hegeliana do trabalho com a sua respectiva crítica marxiana. Assim, antes de precisar o que seja trabalho alienado, é premente que se explicite as implicações que subjazem à formulação marxiana de que Hegel reconhece somente a face positiva do trabalho, malgrado o fato deste, ao fim e ao cabo, ser o trabalho do espírito, desatinando para a sua face negativa.

\footnotetext{
${ }^{9}$ Quanto a essa questão, ver especialmente o $§ 192$ da Filosofia do Direito.
}

\begin{tabular}{|l|l|l|l|l|} 
Revista Dialectus & Ano 1 & n. 1 & Julho-Dezembro 2012 & p. 156-186 \\
\hline
\end{tabular}




\section{Agemir Bavaresco / Márcio E. Schäfer}

Marx obviamente não está focado numa crítica da religião, na auto-alienação religiosa do ser humano, como deixa a entender na seguinte passagem: "primeiramente é tarefa da filosofia, daquela que se encontra a serviço da história [grifo dos autores] depois de ter desvelado a forma religiosa da auto-alienação, desmascarar a auto- alienação em suas formas profanas" (MARX, 1988, p. 379). Portanto, subscrevendo a estrutura geral da análise feuerbachiana da religião, a qual teve por resultado a antropologização do sujeito, Marx parte, neste ponto, para a investigação das formas "profanas" de alienação, as quais têm, como fundamento, uma atividade igualmente material: eis a contribuição de Marx. Em Marx, a atividade é de um sujeito humano, um ser concreto sobre um conteúdo igualmente concreto. Dessa maneira, Marx recusa o ressaibo idealista que perpassou as filosofias de Hegel e Feuerbach, particularmente em torno do conceito de trabalho.

Hegel que, num primeiro instante, sob a influência do pensamento econômico inglês, extraiu o trabalho do véu idealista ao inscrevê-lo na temporalidade histórica, superando a atividade abstrata, moral do idealismo precedente, não conseguiu levá-lo às últimas consequências, à medida que pôs, como sujeito do trabalho, o espírito ou o absoluto. Já para o autor d'O Capital, ao assumir a conclusão de Feuerbach acerca da antropologização do sujeito e de conceber o trabalho como tendo um conteúdo material, a análise do conceito do trabalho assume uma face inteiramente nova. Com efeito, agora, “o homem é um ser que produz socialmente, e que nesse processo se produz a si mesmo. Esse autoproduzir-se - como processo no tempo - faz dele um ser histórico" (SÁNCHEZ VÁZQUEZ, 1968, 423). Eis que, portanto, o trabalho como problema filosófico apeia definitivamente das nevas do idealismo.

Antes de examinar a veracidade da crítica marxiana, é necessário compreender como Marx define a face negativa do trabalho, posta sob a rubrica do problema da alienação, que tem a sua raiz na esfera econômica e não na esfera da religião, não obstante esta seja o pressuposto daquela, pois, como afirma Marx: "Para a Alemanha a crítica da religião está, no essencial, concluída, e a crítica da religião é o pressuposto de toda crítica" (MARX, 1976, p. 378).

Na mesma linha da filosofia hegeliana, Marx não concebe um sujeito dissociado do objeto, nem um objeto independente do sujeito. Assim, tanto o sujeito percipiente quanto o objeto percebido constituem-se a partir de uma série de determinações recíprocas. Com isso, Marx, na esteira de Hegel, distancia-se tanto do materialismo metafísico quanto do idealismo kantiano-fichteano. E no que toca ao sujeito, este só 
vem a desenvolver as suas determinações na medida em que leva a termo a sua ação mediadora com o objeto. A esse propósito, é esclarecedor o comentário de Sánchez Vázquez quando assinala que:

\begin{abstract}
É preciso observar que Marx utiliza duas palavras para designar objeto: na primeira vez diz Gegenstand; na segunda, Objekt. Com essa designação diferente, Marx quer distinguir o objeto como objetivação não só teórica como também prática, e o objeto em si, que é o que entra na relação cognoscitiva segundo o materialismo. Objekt é o objeto em si, exterior ao homem e a sua atividade; o objeto é aqui o que se opõe ao sujeito; algo dado, existente em si e por si, não um produto humano $(1968$, p. 151).
\end{abstract}

Também Marx, seguindo Hegel, acentua o papel ativo da consciência na formação de uma objetividade na qual ela reconhece a si mesma. Ora, se, na análise de Hegel, destrinchou-se justamente essa dimensão formadora do trabalho, a ênfase recairá, agora, sobre o delineamento mais preciso do que constitua a face negativa do trabalho. Antes, contudo, cumpre fazer uma resolução metodológica importante para a análise do complexo problema da alienação, uma vez que "o conceito de alienação é um conceito eminentemente sintético. Isso significa, entre outras coisas, que a palavra 'alienação' não é necessária quando a complexa problemática por ela encoberta é apresentada e desenvolvida de forma detalhada" (MÉSZÁROS, 2009, p. 218). Assim posto, o conceito de alienação pode ser abordado tanto quando se faz menção explícita ao mesmo ou, no linguajar de Mészáros, quando se apresenta minuciosamente as propriedades desse conceito.

O ser humano pode libertar-se do domínio do Objekt, em que a objetividade dada determina a consciência e passa para um estágio em que se institui uma relação recíproca entre o ser humano e o objeto como Gegenstand, que já não mais é encontrado de forma acabada, como um dado natural, mas que corresponde à objetivação teórico- prática do ser humano. Ora, essa objetivação dá-se exatamente através da moldagem da objetividade natural pelo trabalho, através do qual se exterioriza a subjetividade. Cumpre salientar que essa objetividade natural é o substrato pressuposto da ação. Isto implica uma distinção relevante introduzida por Marx no que tange à relação sujeito e objeto tal qual Hegel a concebera, pois, para conceitualizar o objeto, ele joga com o par conceitual Gegenstand e Objekt, de modo a evitar a unificação formal entre sujeito e objeto buscada por Hegel, no saber absoluto, sem, no entanto, abdicar da edificação de uma objetividade conforme a subjetividade, que corresponda à objetivação teórico- prática do sujeito (Gegenstand). Mas, conforme um modo de produção vigente, a possibilidade de interditar essa objetivação teórico-prática torna-se concreta. Desse 


\title{
Agemir Bavaresco / Márcio E. Schäfer
}

modo, ao invés de o sujeito conhecer-se na objetividade produzida acaba por ser dominado por ela. Marx, quanto a isso, registra que:

\begin{abstract}
No que se constitui a alienação do trabalho? Em primeiro lugar, que o trabalho é externo ao trabalhador, isto é, não pertence a sua essência, de modo que por isso ele não se afirma em seu trabalho, mas se nega, não se sente bem, mas infeliz, não desenvolve livremente suas energias físicas e espirituais, mas desgasta seu físico e arruína o espírito. O trabalhador se sente, por isso, em si fora do trabalho e fora de si no trabalho. Ele está em casa quando não trabalha e quando ele trabalha, não está em casa. Seu trabalho não é por isso um trabalho livre, mas coagido, trabalho forçado. Ele não é por isso a satisfação de uma necessidade, mas ele é somente um meio de satisfazer necessidades que lhe são externas (MARX, 2005, p. 59-60).
\end{abstract}

Delineados os aspectos gerais daquilo que se pretende desdobrar, aqui, como a face negativa do trabalho ou o problema da alienação, tal como Mészáros sugere, pode-se perceber que há uma proximidade subjacente à sua formulação, seja nos economistas políticos, seja em Marx. Mas por que ambos sustentam posições prático- teóricas antagônicas? Antes de responder essa questão, ainda que indiretamente, cabe perguntar, agora, sobre como Hegel assimila essa temática em sua obra. Marx está inteiramente correto quando declara que Hegel não reconheceu a face negativa do trabalho?

\subsection{Hegel e as Contradições do Trabalho na Sociedade Civil-burguesa}

Sendo a sociedade civil-burguesa uma das formas mais cristalinas do processo de produção do espírito, do desenvolvimento da Ideia de liberdade na história, não é menos verdade que, em seu âmago, efervescem circunstâncias que interditam a efetivação da liberdade genuína para uma parcela significativa da população, à medida que a liberdade não prescinde de conteúdo econômico. Esse é, aliás, um aspecto notável da filosofia de Hegel, pois reconhece que a liberdade, para poder ser efetivada, exige condições materiais adequadas. Isso contém, in nuce, o núcleo da crítica de Marx às teorias sociais e políticas modernas, que teriam desconsiderado o conteúdo material para a efetivação da liberdade substancial. Adiante, ver-se-á com mais vagar o que, mesmo assim, leva Marx a criticar a posição hegeliana.

O problema central que se coloca, agora, é: como conciliar a saída da naturalidade imediata, da primeira natureza, para o domínio da segunda natureza com um estado de coisas em que o indivíduo é dominado e determinado por forças estranhas? É necessário, pois, investigar mais detalhadamente quais as premissas das quais se segue essa contradição e como Hegel objetiva mediá-la em sua filosofia política. 
O gradativo içamento do ser humano de um estágio imediato, no qual as suas demandas não se expandem para além daquilo que é necessário para a sua sobrevivência - em que ele pode obter os meios para satisfazer as suas demandas com o seu trabalho, concretizado com ferramentas rudes e de forma desorganizada - a um estágio de plena emancipação destas necessidades imediatas implicou consequências bastante complexas. Se ele não mais está sujeito às determinações imediatas, mas mediadas, o repertório de carecimentos a serem satisfeitos expandiu-se vertiginosamente. Como é possível, neste novo cenário, satisfazer a ampla gama de carecimentos? Exige-se um incremento significativo no processo de produção, sem o qual tais carências ficam no mero desejo, de tal forma que o desenvolvimento de novas formas de mediação torna-se inadiável.

A resposta a esse problema é dada com base no trabalho universal, apelando ao adágio do trabalho de todos para todos. Neste contexto de desejos que devem ser satisfeitos a partir do trabalho de todos por todos, Hegel, na sua Filosofia Real, anota:

O Eu-para-si essente é abstrato. É com efeito trabalhador, mas seu trabalho é igualmente abstrato. A carência em geral é analisada em seus muitos lados. $\mathrm{O}$ abstrato em seu movimento é o ser-para-si, o fazer, trabalhar. Porque somente se trabalha para a carência enquanto ser-para-si abstrato, também somente se trabalha de modo abstrato. [...] trabalho universal é assim divisão do trabalho. Dez podem fazer tantos alfinetes como cem. Portanto, cada particular, porque é aqui particular, trabalha para uma carência (HEGEL, 1974, p. 234).

Contudo, sub-repticiamente a esse movimento de abstração, segue-se outra consequência, a qual implica novos problemas do ponto de vista da mediação entre subjetividade e objetividade, pois:

\begin{abstract}
Seu trabalhar se torna completamente mecânico ou pertence a uma determinidade simples. Mas quanto mais abstrata ele se torna, tanto mais ela é somente atividade abstrata e por isso se encontra num estado em que o trabalho pode ser retirado de sua função e ser substituído pela natureza exterior. Ele precisa do simples movimento e este ele encontra na natureza exterior, ou o puro movimento é antes a relação das formas abstratas do espaço e do tempo - a atividade exterior abstrata, a máquina (HEGEL, 1974, p. 235).
\end{abstract}

À medida que a produção de mercadorias requer um simples movimento, visto que a divisão do trabalho seccionou a confecção do produto em inúmeras partes, de modo que cada parte perfaz uma totalidade em si, a qual é, posteriormente, acoplada ao todo verdadeiro, ao produto final, igualmente requer-se um movimento simples, que pode ser conseguido utilizando as forças naturais, não humanas, que podem colocar a ferramenta em ação. A rigor, as faculdades subjetivas do trabalhador tornam-se dispensáveis. 


\section{Agemir Bavaresco / Márcio E. Schäfer}

Hegel, não obstante a agudeza e a perspicácia com que se posiciona quanto à exclusão do trabalhador no processo de produção, no escrito da Realphilosophie, atentando, inclusive, para aspectos que Marx retomaria posteriormente, em especial no que concerne à universalização do mercado e à sua respectiva incidência sobre a vida do trabalhador - desdobra este problema de forma mais definitiva em sua Philosophie des Rechts, conquanto se tenha considerado anteriormente que, em muitos outros aspectos, a crítica social de Hegel, nos escritos pré-sistemáticos, seja mais incisiva. O conceito de "miséria" que, aqui, deve ser considerado sobre os dois vetores já mencionados, a saber, (i) a condição miserável a qual o trabalhador é abandonado nas circunstâncias em que exerce o seu trabalho no seio da sociedade burguesa, e (ii) a sua radicalização com a substituição do trabalhador humano pela máquina, é central para compreender como Hegel intenta desdobrar o problema da face negativa do trabalho. Ele apresenta, de forma acurada o estágio da produção capitalista em que se interrompe o reconhecimento do trabalhador frente ao produto do seu trabalho, isto é, sujeito e objeto acabam por se oporem numa cisão infranqueável. E é importante sublinhar que "esse elemento da alienação no processo do trabalho não é, para Hegel, um aspecto marginal do trabalho que pode ser reformado ou retificado; ele é fundamental e imanente à estrutura da sociedade humana e é uma característica da sociedade moderna [...] intensificá-lo continuamente" (AVINERI, 1972, p. 90).

À primeira vista, este problema constitui o núcleo daquilo que constitui a face negativa do trabalho tal como ele decorre da sociedade civil-burguesa. Segue-se aqui uma reversão de expectativas. A mediação das determinações da primeira natureza, ao invés de conduzir à liberdade, faz com que a objetividade moldada pelo trabalho humano assuma um poder autônomo, estranho, que acaba por dominar os sujeitos. Além disso, na sociedade produtora de mercadorias não com vistas ao valor de uso, mas ao valor de troca, a situação miserável do trabalhador não é um mero epifenômeno. Obviamente, Marx faz uma análise acurada sobre esta sociedade, investigando as categorias econômicas que, conquanto gerem uma riqueza nunca dantes vista, abandona a uma vida miserável parcela significativa de sua população.

O reino da liberdade, que Marx contrapõe ao reino da necessidade, é, neste caso, viável somente se a produção, no dizer de Marx, for controlada pelos produtores livremente associados e não o contrário. Mas, como Hegel compreendeu com bastante lucidez, no embate entre capital e trabalho na sociedade civil-burguesa, a autodeterminação é negada ao trabalho. Sendo o trabalho - o trabalhador - determinado

\begin{tabular}{|l|l|l|l|l|} 
Revista Dialectus & Ano 1 & n. 1 & Julho-Dezembro 2012 & p. 156-186 \\
\hline
\end{tabular}




\section{Agemir Bavaresco / Márcio E. Schäfer}

por outro que não ele, uma consequência irremediável deste processo é o incessante abandono de uma massa significativa da população trabalhadora à miséria absoluta, o que leva Hegel a afirmar, no adendo ao $\S 244$ da Filosofia do Direito, que "a importante questão de saber como eliminar a pobreza tornou-se uma questão que atormenta e agita de modo particular as sociedades modernas".

Hegel, ciente das graves tensões e limites que perpassam a economia moderna, toma distância da tese de Smith, segundo a qual a mão invisível dá conta de mediar as contradições sociais que emanam do moderno modo de produção capitalista. A razão é, neste sentido, abandonada a si mesma na história, devendo encontrar as soluções necessárias para as eventuais instabilidades que instaura no seu devir histórico. Para tanto, quando na esfera das atividades econômicas se instaura o desequilíbrio e a desarmonia, ameaçando a unidade da vida ética, urge pensar alternativas que alavanquem a passagem da razão para um patamar superior de realização, suprassumindo as contradições que ameaçam dilacerá-la. Se "a sociedade civil-burguesa 'põe' simultaneamente, como suas próprias determinações, a riqueza e a miséria” (ROSENFIELD, 1995. p. 208), é ela que deve criar os mecanismos necessários para elidir esta contradição.

Precisamente por isso, na corporação, o indivíduo deve receber a solidariedade necessária para superar a miséria, na qual pode encontrar-se abandonado num período histórico determinado. Pois, "a solidariedade das corporações em relação aos seus membros significa que elas se encarregam da pobreza de modo efetivo, recusando-se a tratar o indivíduo como objeto de mera doação" (ROSENFIELD, 1995, p. 211) ou, ainda, "na corporação, a ajuda recebida pela pobreza perde seu caráter contingente, assim como o seu caráter injustamente humilhante" (HEGEL, § 253 Ad.). Logo, é do amparo da corporação que o indivíduo deve viver quando efetiva-se a sua queda numa situação de miséria, pois, ao ter um sentimento de identificação com a corporação, a dependência de outrem para sobreviver não é totalmente contingente, de modo que não fere a dignidade do trabalhador, que, ao se reconhecer como partícipe da mesma, mantém o elo entre o trabalho, a honra e a autonomia do trabalhador e a satisfação dos carecimentos. 


\subsection{Marx face à teoria da sociedade moderna de Hegel}

Hegel foi o filósofo moderno que se notabilizou pelo projeto de reconciliar a subjetividade com a objetividade. Contudo, como efetivar tal reconciliação no plano ideal-especulativo se a realidade material insiste em manter a cisão entre sujeito e objeto e, pior ainda, cinde o sujeito, o trabalhador de seu próprio produto conferindo a esse um poder independente?

Antes, contudo, é oportuno destacar que, mesmo antes de Hegel, outros filósofos vislumbraram o problema da alienação, da cisão entre sujeito e objeto engendrado pelo modo de produção capitalista, no qual o trabalhador, aquele que produz a riqueza, é abandonado na mais abjeta miséria. Diderot e Rousseau foram vozes que se sobressaíram na denúncia desse estado de miséria, haurido com a instauração do capital como poder soberano de reprodução social. Porém, as alternativas teórico-práticas dadas por esses autores para superar o estado de miséria crescente é proporcionalmente inverso à grandeza de sua crítica e formulação dos problemas decorrentes da sociedade burguesa. Por isso, há que se concordar que:

A superioridade radical de Marx sobre todos os que o precederam é evidente na historicidade dialética coerente de sua teoria, em contraste com as debilidades de seus predecessores, que, em um ou outro momento, foram todos obrigados a abandonar o terreno real da história em favor de alguma solução imaginária das contradições que possam ter percebido, mas que não podiam dominar ideológica e intelectualmente (MÉSZAROS, 2009, p. 45).

Hegel, na esteira destes autores, igualmente atenta para as mazelas que afligem a população trabalhadora com o devir do capital como modo soberano de reprodução social (conforme a seção anterior). Mas, da mesma maneira que Hegel detectou a face negativa do trabalho no modo capitalista de reprodução social, tal como Diderot e Rousseau, as suas tentativas para superá-la foram bastante limitadas.

Ora, se Hegel reconciliou as contradições no plano teórico, torna-se desnecessário superá-las na prática. Com esta nota característica, Hegel se torna a expressão mais perfeita e cabal do idealismo alemão, pois, “em última instância, Hegel permanece um quietista, pesquisando por uma solução que poderia incorporar esta realidade horrível [a alienação] num sistema que pudesse integrá-la e acomodá-la. A filosofia só pode interpretar o mundo, não transformá-lo" (AVINERI, 1972, p. 99).

Contra essa posição teórica, Marx, na undécima das Teses ad Feuerbach, afirma que "os filósofos se limitaram a interpretar o mundo, cabe agora transformá-lo", ou seja, a tarefa da filosofia não se restringe a interpretar o mundo como uma totalidade 
coerente, mas há de levar à sua transformação. Isso significa que, no transcurso de suas investigações, Marx está meridianamente longe de desenvolver uma crítica meramente moral da degenerescência do trabalhador na sociedade produtora de mercadorias com vistas à autoexpansão do capital.

Diferente de Hegel, Marx recusa que as mediações para as contradições que grassam na sociedade moderna possam ser forjadas pura e simplesmente no âmbito teórico. Embora aceite integralmente o desenvolvimento do método dialético tal como efetuado por Hegel, a sua aplicação não há de ser concretizada no âmbito idealespeculativo, mas na realidade histórico-concreta. Ora, destituindo o trabalho de toda e qualquer mistificação teórica, igualmente as contradições que dele emergem não podem ser suprassumidas na teoria. O projeto filosófico de Marx define-se, assim, exatamente na teorização da totalidade social com vistas à superação prático-revolucionária da sociedade capitalista que engendra essas contradições. A alienação do trabalhador pelo seu trabalho deve ser superada revolucionando a anatomia da sociedade civil-burguesa que a engendra, ou seja, o objeto da teoria deve ser a tematização crítica da economia política, a qual dá conta de destrinchar a estrutura de funcionamento da sociedade civilburguesa e as suas contradições não com vistas a mitigá-las no Estado, mas para revolucioná-las ${ }^{10}$. Aliás, Hegel, ao querer mediar as contradições da sociedade civilburguesa nesses moldes, não as medeia em absoluto, pois “o verdadeiro é precisamente que a sociedade civil determina o Estado" (SÁNCHEZ VÁZQUEZ, 1980, p. 15) e não o contrário, de modo que está fora do escopo de ação do Estado mediar genuinamente as tensões da sociedade civil.

Ora, como conceitualizar a novidade filosófica de Marx em relação aos seus predecessores críticos da sociedade capitalista? Essa conceitualização pode ser dividida em dois níveis: (i) a carência de um instrumental metodológico adequado para tematizar a sociedade moderna como uma totalidade articulada, como em Diderot ou Rousseau, o que os impediu de teorizar num nível histórico a origem das contradições sociais, de modo que as soluções por eles apresentadas não podiam passar de postulados morais abstratos deshistoricizados, e (ii), mesmo de posse de um método adequado para executar uma totalização reflexiva da sociedade, o mistificar desse método, como em

\footnotetext{
${ }^{10}$ Isso define basicamente todo o projeto teórico-prático de Marx. A Crítica da Economia Política, que igualmente abrange a crítica da política, é o objeto das investigações marxianas a partir do conjunto de questões que as teorias sócias e políticas modernas não conseguiram responder. Por isso, não há como querer explicitar aqui todas as implicações da relação entre economia e política em Marx, restringindo-se a afirmar a recusa de Marx de tratar essa questão nos moldes hegelianos, ou seja, de mediar as contradições da sociedade civil-burguesa numa esfera exterior, qual seja: o Estado.
}

\begin{tabular}{|l|l|l|l|l|} 
Revista Dialectus & Ano 1 & n. 1 & Julho-Dezembro 2012 & p. 156-186 \\
\hline
\end{tabular}


Hegel, que propugna uma solução para as contradições somente no nível idealespeculativo.

Desvelada a estrutura "mística” da dialética em Hegel, Marx pensa ter demonstrado o caráter histórico da moderna sociedade capitalista e, com isso, a contingência das contradições sociais, cujo ponto de culminância é o problema da alienação. A tarefa que se apresenta, em continuidade, é a de encontrar o sujeito que pode levar a termo a superação das contradições sociais capitalistas e, por conseguinte, a alienação do trabalhador. A dialética especulativa de Hegel transforma-se, assim, num pressuposto básico para a transformação revolucionária da sociedade capitalista, autorizando a afirmação segundo a qual Marx, não obstante a centralidade de Feuerbach na passagem do trabalho do espírito ao trabalho humano na filosofia alemã clássica, isto é, da antropologização do sujeito do trabalho, permanece, apesar do ajuste de contas crítico com o método hegeliano, um seguidor desse. Em última instância, Feuerbach enreda-se no dualismo teoria/prática, com o qual restringe a sua compreensão da realidade como uma totalidade racionalmente estruturada. Isso só é possível com a concepção monista de Hegel.

Exatamente essa é a crítica de Marx à economia política clássica, ao invés de provar o seu objeto, assenta-o na natureza, no "dado"11. Entretanto, a compreensão da dialética em Marx, mesmo ponderando o seu débito com Hegel, requer as devidas diferenciações, uma vez que, se, em Hegel, as determinações do pensamento têm proeminência, em Marx, as determinações do real devem prevalecer.

Efetuada essa inversão, isto é, a dialética não mais apresentando as determinações do pensamento, a totalidade ideal-especulativa, mas a totalidade do real, as determinações históricas, é possível asseverar categoricamente que "é este o modelo dialético que Marx adotou de Hegel” (IBER, 2000, p. 20). A mudança central para que essa efetivação seja possível deve ocorrer no "motor" que impele a dialética a progredir no seu desenvolvimento. Contrapondo-se à posição hegeliana do que seja o sujeito do trabalho, especialmente nos escritos sistemáticos, o espírito ou o absoluto, Marx assenta o sujeito do movimento no(s) trabalhador(es) concreto(s), incrustado(s) na história. Assim posto, as contradições sociais que têm como consequência o problema da

\footnotetext{
${ }^{11}$ Smith, na sua Wealth of Nations, fornece uma caracterização exata do que está em questão. Afirma ele que "essa divisão do trabalho, da qual derivam tantas vantagens, não é originalmente efeito da sabedoria do homem, que prevê e intenta a opulência, a qual ela dá ocasião. Ela é consequência necessária, embora lenta e gradual, de certa propensidade na natureza humana, a qual não tem em vista tal utilidade prolongada; a propensão para transportar, negociar e trocar uma coisa por outra" (1952, p. 6).
}

\begin{tabular}{|l|l|l|l|l|l|} 
Revista Dialectus & Ano 1 & n. 1 & Julho-Dezembro 2012 & p. 156-186 \\
\hline
\end{tabular}




\section{Agemir Bavaresco / Márcio E. Schäfer}

alienação não podem ser suprassumidas apenas no plano da teoria. Neste ponto, aparece um aspecto importante da obra marxiana, especialmente o problema que diz respeito ao "sujeito" na referida obra, em que, não raro, se acusa Marx de tê-lo esquecido em suas investigações econômicas. O ponto crucial é que, para Marx, o significado ontológico fundamental do trabalho, a sua função na efetivação das potências subjetivas, não pode ser concretizada sem uma estrutura social favorável. Por isso, quando se percebe que a sociedade burguesa, regida pela autovalorização do valor, implica uma negação desse significado ontológico fundamental, é ela - a estrutura social - que deve ser tematizada com vistas à sua suprassunção.

Assim, pode-se afirmar, com segurança, que mesmo Hegel reconhecendo a face negativa do trabalho, a separação do trabalhador e do produto, mais cabalmente, na dominação daquele por este, não desdobra uma tematização em nível histórico de sua origem. E, conforme já se afirmou, a aceitação acrítica dos postulados da economia política clássica, tomando-os como a forma natural da sociedade, determina a tematização completamente a-histórica das categorias econômicas que implicam a alienação. Por isso, vale reiterar, mais uma vez, a crítica de Marx ao ponto de vista epistemológico de Hegel, a saber, "o ponto de vista dos modernos economistas nacionais". E, no comentário certeiro de Mészáros, “partilhar 'do ponto de vista da economia política’ significa ser incapaz de desenvolver em termos concretos as condições de uma verdadeira superação [da alienação]" (2009, p. 115). A consequência é o deslocamento de um problema de fundo histórico, como é o problema do trabalho e da auto-alienação do trabalhador pelo seu trabalho, para o plano da não-historicidade, na qual qualquer solução não transcende o âmbito ideal.

Desta feita, aquilo que se apresentou como um avanço da filosofia de Hegel, isto é, o tratamento histórico-concreto do trabalho, contraposto à concepção metafísico- abstrata de atividade, lugar comum no idealismo alemão anterior, acaba por assumir uma face problemática, para não dizer paradoxal. Marx, ao contrário, refuta a concepção de trabalho como sendo o trabalho do espírito, o que o leva a tematizá-lo integralmente no plano histórico-material. O trabalho é o trabalho do sujeito concreto, do trabalhador como proletário, de modo que qualquer contradição que surge dentro da atividade mediadora do trabalho deve ser solucionada nos seus limites. Assim sendo, "Hegel não encobre com uma cortina essas consequências negativas do trabalho, mas, nesse ponto, não pode ir muito além dos economistas ingleses, porquanto ignora a raiz de classe, 
social de sua negatividade. Se a tivesse descoberto, deixaria de ser Hegel e passaria a ser Marx" (SÁNCHEZ VÁZQUEZ, 1968, p. 69).

\section{Referências Bibliográficas}

ARANTES, P. Hegel: a Ordem do Tempo. Tradução Rubens Torres Filho. São Paulo: Ed. Polis, 1981.

AVINERI, S. Hegel's Theory of the Modern State. New York: Cambridge University Press, 1972.

BOURGEOIS, B. Os Atos do Espírito. Trad. Paulo Neves da Silva. São Leopoldo:

Editora Unisinos, 2004.

FLICKINGER, H. G. Marx e Hegel. O porão de uma filosofia social. Porto Alegre: LPM, 1986.

HEGEL, G. W. F. Enziklopädie der philosophische Wissenschaften. Jubileumsausgabe in zwanzig Bänden. Stuttgart: Frommanns Verlag, 1956.

. Phänomenologie des Geistes. Jubileumsausgabe in zwanzig Bänden.

Stuttgart: Frommanns Verlag, 1951. Edição brasileira: Fenomenologia do Espírito. Petrópolis: Ed. Vozes, 1992.

Philosophie des Rechts. Jubileumsausgabe in zwanzig Bänden. Stuttgart: Frommanns Verlag, 1952. Edição brasileira: Linhas Fundamentais da Filosofia do Direito. São Paulo: Loyola; São Leopoldo: Unisinos, 2010.

. Vorlesungen über die Geschichte der Philosophie. Jubileumsausgabe in zwanzig Bänden. Stuttgart: Frommanns Verlag, 1949a.

. Wissenschst der Logik. Band I. Jubileumsausgabe in zwanzig Bänden.

Stuttgart: Frommanns Verlag, 1958.

. Wissenschst der Logik. Band II. Jubileumsausgabe in zwanzig Bänden.

Stuttgart: Frommanns Verlag, 1949b.

. System der Sittlichkeit. Herausgegeben und Kommentiert von Gerhard Göhler. Frankfurt/M-Berlin-Wien: Verlag Ullstein GmbH, 1974.

Realphilosophie. Herausgegeben und Kommentiert von Gerhard Göhler. Frankfurt/M-Berlin-Wien: Verlag Ullstein GmbH, 1974.

\begin{tabular}{|l|l|l|l|l|} 
Revista Dialectus & Ano 1 & n. 1 & Julho-Dezembro 2012 & p. 156-186 \\
\hline
\end{tabular}


HYPPOLITE, J. Gênese e Estrutura da Fenomenologia do Espírito de Hegel. Trad. Andrei José Vaczi et alii. São Paulo: Discurso Editorial, 1999.

IBER, C. Grundzüge der Marxschen Kapitalismustheorie. Berlin: Parerga Verlag, 2005.

"Was will Hegel eigentlich mit seiner Wissenschaft der Logik? Kleine

Einführung in Hegels Logik". In: Hegels Seinslogik: Interpretationem und Perspektiven. Org. Andreas Arndt/Christian Iber. Berlin: Akademie Verlag, 2000.

JARCZYK, G. "O conceito do trabalho e o trabalho do conceito em Hegel”. In: Revista de Filosofia Política, Porto Alegre, v. 1, p. 115-129, 1984.

KANT, I. Kritik der reinen Vernunft. Insel-Verlag Zweigestelle: Wiesbaden, 1956.

MARX, K. \& ENGELS, F. Die Deutsche Ideologie. Werke, Band 3. Berlin: Dietz Verlag, 1990.

MARX, K. Das Kapital. Werke, Band 23. Berlin: Dietz Verlag, 1993.

. Grundrisse der Kritik der politischen Ökonomie. Werke, Band 42.

Berlin: Dietz Verlag, 1983.

. Zur Kritik der Hegelschen Rechtsphilosophie. Einleitung. Werke, Band

1. Berlin: Dietz Verlag, 1976.

Verlag, 2005.

Ökonomisch-philosophische Manuskripte. Hamburg: Felix Meiner

MÉSZÁROS, I. A Teoria da Alienação em Marx. Trad. de Isa Tavares. São Paulo: Boitempo editorial, 2009.

ROSENFIELD, D. Política e Liberdade em Hegel. São Paulo: Editora Ática, 1995. - "La Ciencia de la Lógica de Hegel como Filosofía primera". In:

Cuadernos Filosóficos Homo Sapiens, v. IV, p. 155-168, 2007.

SCHMIDT AM BUSCH, H-C. Hegels Begriff der Arbeit. Berlin: Akademie Verlag, 2002.

SMITH, A. The Wealth of Nations. Great Books of Western World, 1952.

VÁZQUEZ, A. S. Filosofia da Práxis. São Paulo: Ed. Paz e Terra, 1968.

. Filosofía y economía en el joven Marx. Ciudad de México: Grijalbo, 1983

\begin{tabular}{|l|l|l|l|l|} 
Revista Dialectus & Ano 1 & n. 1 & Julho-Dezembro 2012 & p. 156-186 \\
\hline
\end{tabular}

